\title{
СУЧАСНІ АСПЕКТИ ОРГАНІЗАЦІЇ ВИКЛАДАННЯ КЛІНІЧНОЇ ФАРМАЦІЇ СТУДЕНТАМ ФАРМАЦЕВТИЧНОГО ФАКУЛЬТЕТУ
}

I. В. Мерецька

ДВНЗ “Тернопільський держсавний медичний університет імені І. Я. Горбачевського МОЗ Украйни”

\section{MODERN ASPECTS OF ORGANIZATION OF TEACHING THE CLINICAL PHARMACY FOR STUDENTS OF PHARMACEUTICAL FACULTY}

\author{
I. V. Meretska \\ SHEI “Ternopil State Medical University by I. Ya. Horbachevsky of MPH of Ukraine”
}

\begin{abstract}
Стрімкий розвиток фармацевтичного виробництва, поява значного числа оригінальних та генеричних засобів, розширення меж “самолікування" вимагають підвищення якості підготовки провізорів і передбачають глибокі знання основних питань етіології, патогенезу, симптоматики найважливіших захворювань, фундаментальних понять і проблем загальної та спеціальної фармакології, критеріїв діагностики невідкладних станів, методології вибору найбільш ефективних і безпечних лікарських засобів.
\end{abstract}

The rapid development of pharmaceutical production, the emergence of large number of original and generic drugs, expanding the limits of "self-treatment" requires improving the quality of training of pharmacists and provides in-depth knowledge of basic issues of etiology, pathogenesis, symptoms of major diseases, the fundamental concepts and problems of general and special pharmacology, diagnostic criteria of emergency conditions and methodology of selecting the most effective and safe medicines.

Вступ. Медикаментозна терапія застосовується в абсолютної більшості хворих і за прогнозами у XXI сторіччі очікується збільшення кількості жителів старших вікових груп, що призведе до неминучого зростання захворюваності та необхідності індивідуалізації лікування. Впровадження у клінічну практику великої кількості лікарських засобів (ЛЗ) вимагає вивчення не тільки ефективності і безпеки їх застосування, але й створення єдиної методології для дослідження фармакокінетики, фармакодинаміки, взаємодії і побічної діїліків у хворих [1]. Це обгрунтовує введення у програму підготовки провізора предмета клінічної фармації, яка являє собою інтегрований досвід багатьох галузей медико-біологічних знань i, перш за все, досвід щодо індивідуалізованого застосування лікарських засобів.

Основна частина. Мета викладання клінічної фармації - навчити майбутнього провізора методології вибору найбільш ефективних і безпечних лікарських засобів або їх комбінацій для інформації лікарів на основі знань фармакокінетики, фармакодинаміки, фармакогенетики, фармакоепідеміології, фармакоекономіки, взаємодії лікарських засобів, небажаних медикаментозних реакцій, принципів доказової медицини тощо.
Викладання клінічної фармації провізорам проводиться відповідно до діючої навчальної програми, яка структурована на модулі, змістові модулі, теми. Програму поділено на 3 модулі: модуль 1 - загальні питання клінічної фармації, клінічна фармація в кардіології, ревматології, пульмонології, нефрології; модуль 2 -клінічна фармація в гастроентерології, гепатології, гематології, ендокринології, алергології; модуль 3 фармацевтична опіка під час випуску безрецептурних лікарських препаратів.

Відповідно до навчального плану викладання клінічної фармації для студентів фармацевтичного факультету здійснюється у 8 семестрі (IV курс) і 9 семестрі (V курс) - всього 378 годин (10,5 кредитів).

Засвоєння дисципліни здійснюється за допомогою лекцій, практичних та семінарських занять, самостійної роботи студентів, консультацій. Лекційна програма нерозривно пов'язана з програмою практичних занять. Завдання лекційного курсу полягає в тому, щоб дати орієнтацію у поняттях симптомів і синдромів основних захворювань внутрішньої медицини, у здійсненні принципу вибору ефективних і безпечних груп лікарських засобів, а також вибору конкретного препарату з урахуванням функціонального стану організму хворого. 
Завдання практичних та семінарських занять - формування вмінь та навичок, необхідних для діяльності провізора у галузі забезпечення лікарів і споживачів лікарських засобів інформацією з клінічної фармакології препарату з метою найбільш раціонального його застосування. Основний акцент робиться на різні форми практичної роботи студента, спрямовані на активізацію навчально-пізнавальної діяльності студентів на основі позааудиторної самопідготовки, роботи на практичних заняттях, знанні та вмінні виконувати передбачені програмою практичні навички.

Практичні заняття передбачають роботу біля ліжка хворого з визначенням симптомів і синдромів захворювання, збір лікарського анамнезу, ознайомлення $з$ медичною документацією (історією хвороби), аналіз листків лікарських призначень, визначення критеріїв ефективності та безпеки призначеної лікарської терапії.

Оптимальною формою практичної роботи є система клініко-ситуаційних завдань, розроблених на кафедрі, які повинні передбачати проведення інформаційно-пошукової роботи провізора щодо вибору лікарських засобів з оформленням протоколу призначення ефективних і безпечних груп, рекомендації необхідних методів контролю за ефективністю і безпечністю обраного препарату із зазначенням можливих небажаних медикаментозних реакцій і оцінкою вірогідності їх розвитку і способів корекції.

Зметою підвищення творчої активності майбутніх спеціалістів усі види роботи студента об'єднуються у виконання курсової роботи (науково-практичної самостійної роботи), що сприяє розвитку у студентів навичок роботи з літературою, вчить узагальнювати та використовувати отримані знання.

На кафедрі розроблені навчально-методичні матеріали у вигляді методичних вказівок для студентів, матеріалів для підготовки студентів до лекцій та практичних занять, створений банк тестових завдань для проведення щоденного альтернативного дистанційного контролю знань студентів за системою "Moodle" та семестрового тестового іспиту.

Заняття складається з таких трьох частин, як: практична частина, семінарське обговорення і контроль знань. За кожну частину студент отримує оцінку, потім всі оцінки додаються і виставляється вже єдиний сумарний бал за конкретне заняття.

У сучасних умовах відбуваються суттєві зміни у функціональних обов'язках провізора. Спеціалісту фармації, особливо зайнятому безпосереднім відпуском ліків, недостатньо вміти вільно орієнтуватися у фундаментальних поняттях і проблемах загальної і спеціальної фармакології, порівняльній характеристиці нових препаратів, їх ефективності і безпечності, взаємодії між собою і з їжею. Необхідним також є знання основних питань етіології, патогенезу, симптоматики найважливіших захворювань, навичок діагностики невідкладних станів. Це важливо для кваліфікованої консультації пацієнтів, здійснення фармацевтичної опіки. Особливе значення мають препарати безрецептурного відпуску (ОТС-препарати), частка яких становить більше $65 \%$ асортименту ліків; вони являють собою “зону особливої відповідальності” фармацевтичного працівника. Значне збільшення кількості готових лікарських форм, розширення номенклатури лікарських засобів, що відпускаються без рецепта лікаря, самолікування приводять до того, що все більше місце в професійній діяльності провізора набуває консультативно-інформаційна робота, фармацевтична допомога. У зв'язку з цим випускнику фармацевтичного факультету доводиться виступати в ролі консультанта по вибору лікарського препарату, вибору його найбільш придатної лікарської форми, часу і режиму прийому з метою забезпечення максимальної і безпечної фармакотерапії.

Провізор, який є часто єдиним консультантом 3 лікарського препарату, повинен вияснити, для усунення якого симптому вибирається засіб. Важливо визначити (на основі опитування пацієнта), чи не є даний симптом проявом захворювання, яке вимагає обов'язкового звернення до лікаря; визначити фармакологічну (фармакотерапевтичну) групу ЛЗ для усунення даного симптому; вибрати серед ЛЗ певної групи оптимальний для даного пацієнта. Все це стає можливим при вивченні фармацевтичної опіки як розділу клінічної фармації.

У процесі освіти найбільш важливе завдання - безперервне випереджаюче інформування студентів про останні розробки, які потенційно використовуватимуться у клінічній практиці з урахуванням принципів раціональної фармакотерапії з позицій доказової медицини [2]. Тому кардинальним завданням вищої медичної і фармацевтичної школи є підготовка спеціалістів з фундаментальною професійною освітою, що забезпечує глибоке знання проблеми, професійну компетентність і мобільність спеціалістів [3]. В аптеці знання клінічної фармації допомагає орієнтуватись у величезній масі Л3, щоб не нашкодити хворим і здоровим людям. Ці знання допомагають у спілкуванні зі споживачами, сприянні їм у виборі ЛЗ.

Висновок. Таким чином, теоретичною базою для проведення консультативної роботи серед лікарів і населення з питань раціональної лікарської терапії, a 
також для здійснення фармацевтичної опіки пацієнтів $\epsilon$ клінічна фармація.

В умовах стрімкого розвитку фармацевтичного виробництва, появи значного числа оригінальних та генеричних засобів, встановлення ринкових відносин, розвитку тенденції розширення меж “самолікуван-

\section{Література}

1. Крауз В. А. Об опыте преподавания клинической фармакологии на фармацевтическом факультете / В. А. Крауз, Е. В. Коноплева // Мат. научн.-практич. конф. с международным уч. "Подготовка кадров для фармацевтической отрасли : вызовы времени”, посвященной 90-летию СПХФА, 2009.-С. 178-180. ня” передбачається підвищення ролі провізора як активного помічника лікаря і консультанта пацієнта. Без знань клінічної фармакології препаратів провізор не зможе реально оцінити ефективність і безпечність засобів, що рекламуються, і протистояти в деяких випадках агресивній рекламній політиці.

2. Хапалюк А. В. Общие вопросы клинической фармакологии и доказательной медицины : пособие / А. В. Хапалюк. - Мн. : Промпечать, 2007. - 74 с.

3. Вдовиченко Ю. Дискусійні питання безперервного професійного розвитку / Ю. Вдовиченко, О. Вернер, Д. Головань // Ваше здоров’я. - 2007. - № 6. - С. 8. 